\title{
LIFE-HISTORY TRAITS AND THE FIRST DEMOGRAPHIC DATA OF IRANIAN POPULATION OF THE WEST ASIAN LEMON-YELLOW TREE FROG, HYLA SAVIGNYI (AUDOUIN, 1827)
}

\author{
Raziyeh Alaei ${ }^{1}$, Alireza Pesarakloo ${ }^{* 1}$ \\ Masoumeh Najibzadeh ${ }^{2}$ and Sayed Jamal Mirkamali ${ }^{3}$ \\ ${ }^{1}$ Department of Biology, Faculty of Science, Arak University, 3813853945 Arak, Iran \\ E-mail: alaeiraziye@gmail.com; https://orcid.org/0000-0003-0043-3669 \\ ${ }^{2}$ Iranian Plateau Herpetology Research Group (IPHRG), Razi University \\ 6714967346 Kermanshah, Iran; E-mail: Masoumeh.najibzadeh@gmail.com; https://orcid.org/ \\ ${ }^{3}$ Department of Mathematics, Faculty of Science, Arak University \\ 3813853945 Arak, Iran; E-mail: Mirkamali.sj@gmail.com; https://orcid.org/ \\ *Corresponding author's e-mail: a.pesarakloo@gmail.com, https://orcid.org/0000-0002-5599-6525
}

The life-history of an organism consists of its lifetime pattern of growth, development, storage, age, and reproduction. In this study, some life-history traits of Hyla savignyi were studied in populations from different parts of Iran. The microscopic and macroscopic analysis showed that testicular activity in $H$. savignyi is potentially continuous, reaching its peak level in April. Metamorphosis was completed in approximately 102 days after egg deposition, and body size at metamorphosis was $10 \mathrm{~mm}$. Significant sexual size dimorphism was present in all populations, and a larger female asymptotic body size was observed (43.07 $\mathrm{mm}$ for females vs $41.16 \mathrm{~mm}$ for males). The adult survival rate (S) and life expectancy (ESP) were the same for both sexes $(S=0.73$ and $\mathrm{ESP}=4.2$ years). Age and body size were positively correlated with each other for both females and males. Maximum longevity was recorded to be six years in both females and males, and ages of sexual maturity were estimated to be two or three years in breeding individuals. The adult sample age ranged from two to six years (mean age of females: $4.40 \pm 0.68$ years; males: $3.63 \pm 0.13$ years). Our data confirm the general patterns of body size variation and mean age in anurans and show that females are larger than males and live longer.

Key words: life-history, Hyla savignyi, metamorphosis, sexual size dimorphism (SSD), survival rate, life expectancy, tree-frog.

\section{INTRODUCTION}

The amphibian growth rate is influenced by temperature, rainfall and humidity, diet, competition, predation, and intrinsic characteristics, e.g., body length and egg size (Duellman \& Trueb 1986, Berven 1982). A variation in these characters is correlated with altitude and latitude; they can potentially be used to assess amphibians' lifespan under different climatic conditions (Berven \& Chadra 1988, Berven et al. 1979). Sexual maturity is an important phase in the life-history of any organism, and parameters such as age, size, and the formation of sex cells define this stage (Bernardo 1993, Adolph \& POrTER 1996). There are various hypotheses regarding how biotic and abiotic 
factors influence age, length, and body size at sexual maturity; the optimal timing of sexual maturity is ideally achieved when the costs and benefits of maturing at different ages and lengths are balanced around an equilibrium point or along with a reaction norm (STEARns \& Koella 1986). Intraspecific phenotypic plasticity provides an important source of information for studying the evolution of life-history traits and adaptation to different environmental pressures (BERVEN 1982). The traits that constitute an organism's lifehistory can also be seen as "coadapted and designed by natural selection to solve a particular ecological problem" (STEARNs 1976), which in turn makes it important whether diversity among populations and species is generally phenotypic or genotypic (Berven \& GILL 1983).

Spermatogenesis is one of the basic aspects of the reproductive cycle in vertebrates (Konvalina et al. 2018). The annual spermatogenic cycles in anurans have been grouped into three main categories: continuous, discontinuous and potentially continuous (Lofts 1974, KAPtan \& MurathanoĞLu 2008). Tropical species occurring in environments that do not show major fluctuations in climatic conditions have evolved a continuous spermatogenic cycle (Kaptan \& MurathanoĞLu 2008) indicated by the continuous presence of spermatozoa in the testes throughout the year (Lofts 1974, SAsso-CERri et al. 2004). Spermatogenesis in temperate anurans is completely seasonal and can take the form of either discontinuous or potentially continuous types (KAPTAN \& MurathanoĞLu 2008). In the discontinuous type, males enter an inactive sexual phase after spawning; in the potentially continuous type, they show a partial cessation of spermatogenic activity during certain seasons of the year, though primary spermatogonia remain sensitive gonadotrophic stimulation (HuANG et al. 1997).

In the case of inter-population variation, amphibians are often well suited for life-history studies. Many amphibian populations show marked fluctuations in size and age structure (DrISCOLL 1999). Knowledge of variation in age and body size of individuals is necessary to develop management plans and protect amphibian populations in their natural environment (DRISCOLL 1999).

Age determination studies, in particular, are needed to understand the dynamics and life-history of populations of amphibians and reptiles. The skeletochronology of amphibians has been widely established for around three decades (Gibbons \& McCarthy 1986, Morrison et al. 2004, McCreary et al. 2008). The effects of climate conditions on the ectotherm vertebrate metabolism are recorded in their growth by the formation of lines of arrested growth, LAGs, providing a suitable method for determining age in natural populations (Olgun et al. 2005). The cool season gives rise to narrow and dark rings in bone corresponding to reduced growth and higher concentrations of organic and inorganic materials; in contrast, the warm season leads to the formation of looser and wider rings (Gibbons \& McCarthy 1986, Morrison et al. 2004). 
The West Asian Lemon-yellow Tree Frog, Hyla savignyi (Audouin, 1827) is widely distributed in western Asia. In Iran, it can be found in the North, West and Southwest regions of the Iranian plateau at sites with permanent water and dense grass in the Zagros and Alborz Mountains, at altitudes ranging from 350 to $2000 \mathrm{~m}$ (Baloutch \& Kami 1995, Cheatsazan et al. 2005). We collected samples of $H$. savignyi from some populations in Iran. The primary aim of our study was to determine testicular activity, reproduction season, and time and size at metamorphosis in $H$. savignyi of these populations. We also analyzed and compared the growth rate, age structure, age at sexual maturity, and longevity in the species.

\section{MATERIALS AND METHODS}

Study area and sampling - The study areas were located in two Iranian Provinces, Lorestan and Markazi. Frog samples were collected under permit 95/10168 granted by the Iranian Department of Environment. Surveys were conducted at night from March to October 2019 in various aquatic habitats, including ponds, unstable stagnant waters, rock and soil pools, wetlands, and creeks. A total of 72 specimens ( 67 males, 5 females) of $H$. savignyi were caught by hand. Snout-vent length (SVL) was measured with a digital calliper to the nearest $0.01 \mathrm{~mm}$. The second segment was cut from the longest toe (4th) of the right or left hindlimb and placed in formaldehyde (10\%) for histological analysis from each specimen. Examined female frogs were subsequently released at the collection site of their capture, whereas males were transported to the Zoology Laboratory, Arak University, Arak, Iran, for use in the histological analysis of the gonads to estimate the reproductive season.

Reproductive season - Male frogs were euthanized with chloroform, and their gonads were removed and placed in formaldehyde $(10 \%)$. All experimental procedures and animal care were performed according to the protocols approved by the Department of Biology of Arak University. Histological preparations were made according to BANCROFT and Stevens (1990). Each testis was dehydrated in alcohol, cleared in xylene, embedded in paraffin wax at $56^{\circ} \mathrm{C}$ (melting point), then sectioned at 5-7 $\mu \mathrm{m}$ thickness. Each section was then stained using the Hemotoxylin and Eosin ( $\mathrm{H} \& \mathrm{E})$ staining method. Cross-sections prepared from each sample were examined to detect different types of spermatogenic cells, such as spermatogonia, primary and secondary spermatocytes, spermatids, and free spermatozoa. According to Behera (2012), during the spawning season, testis lobules of the banded gourami (Trichogaster fasciata), a seasonally breeding tropical freshwater fish, were completely packed with spermatozoa, the testicular and lobular walls became thinner, and the intralobular space decreased, whereas in the post-spawning season there was a remarkable decrease in spermatozoa. We used the above pattern to interpret the cross-sections of male gonads of $H$. savignyi, because there is the same reproductive pattern in both species (Rugr 1951). We compared mean testis size (testis length) and weight in different months of the year. Descriptive statistics, a one-way analysis of variance (ANOVA) and Scheffe's post hoc tests were used to analyze seasonal variation in histological and quantitative studies.

Age determination - Age estimation was performed using the standard method of skeletochronological analysis according to CASTANET and SMIRINA (1990) by counting the lines of arrested growth (LAGs) in stained cross-sections of the phalangeal bones (Jin et al. 2017). Phalanges were decalcified in nitric acid (5\%), and after dehydration, serial sections $(18-20 \mu \mathrm{m})$ from the mid-diaphyseal region were cut using a freezing microtome and then 
stained with H \& E. Cross-sections were explored under both a light microscope (Olympus BX51) and Scanning Electron Microscopy (SEM). The cross-sections were fixed under a light microscope (Olympus BX51) and were independently confirmed by two observers for age estimation. Longevity (maximum lifespan) was estimated according to OTERo et al. (2017) as the maximum number of LAGs counted in adults. To estimate age at sexual maturity, we used a combination of three methods (average of all three methods): 1 . the smallest distance between two subsequent LAG (RYSER 1998); 2. the minimum number of LAG counted in breeding individuals (ОтеRо et al. 2017); and 3. lowest age recorded amongst the breeding individuals (ARISOY \& BAşKALE 2019).

Growth estimation - We used Shapiro-Wilk's test to assess normality and the MannWhitney U-test test to compare the age structure between sexes. Sexual size dimorphism was computed according to the sexual dimorphism index, where SDI = (average length of larger sex/average length of smaller sex) \pm 1 ; the result is arbitrarily defined as positive $(+1)$ if females are larger than males, and negative (-1) if males are the larger sex (Lovich \& GibBons 1992). Survivorship rate for adults of this species was calculated by the following formula: $\mathrm{S}=\mathrm{T} /(\mathrm{R}+\mathrm{T}-1)$, where $\mathrm{S}$ is the finite annual adult survival rate estimate, $\mathrm{T}=\mathrm{N} 1+2 \mathrm{~N} 2+\ldots$ $+\mathrm{nNn}, \mathrm{R}=\Sigma \mathrm{Ni}$, and Ni described as the number of the adult in the age group $\mathrm{i}$. Adult Life expectancy (ESP) was computed by the formula of SEBER (1973), where ESP $=[0.5+1 /(1-S)$ and $S=$ adult survival rate. As with the general patterns of ectotherms, amphibian growth follows an S-shaped curve (von BERTALANFFY 1957). The growth rate was assessed according to the von Bertalanffy equation: SVLt $=$ SVLasym.max $(1 \mathrm{e}-\mathrm{k}(\mathrm{t}-\mathrm{t} 0))$, where age at metamorphosis is t0, SVL at the age of metamorphosis is SVLt0, and the growth coefficient called $\mathrm{k}$ (vON BertalanfFy 1957). To determine the age and size at metamorphosis, one egg clutch of $H$. savignyi was collected from a natural and clean pond in the Makhmalkoh -Khorramabad region $48.30^{\circ} \mathrm{N}, 33.59^{\circ} \mathrm{E}$ and $1300 \mathrm{~m}$ above sea level (a.s.l.), on 21 January 2017. Clutches were stored in separate polyethylene tubs $(600 \times 400 \times 250 \mathrm{~mm})$ filled with water from the natural habitat and transported to the Biology Laboratory, Arak University, Arak, Iran. We used the NLS method in "stats" package on R software to fit the Bertalanffy model.

\section{RESULTS}

\section{Reproductive season}

We found that peak reproductive activities (spawning season) in $H$. savignyi occur from late March to late April (Fig. 1a), and the period of lowest sperm production (post-spawning season) was during the cool season from August-February (Fig. 1b). Microscopic examination of the histological sections of male testes indicated that the total length of the breeding season was somewhat longer, from late March to late July; after that, the number of cells in the final stages of spermatogenesis (spermatids and sperm) gradually declines. During this period, the germinal layer begins to rebuild, and only spermatogonia and spermatocytes can be observed in the seminiferous tubules. Besides, the interstitial tissue thickness increased during this period, and the lumen of seminiferous tubules contained large ducts almost devoid of sperm. This is a confirmation of our statistical analysis (Fig. 1). 


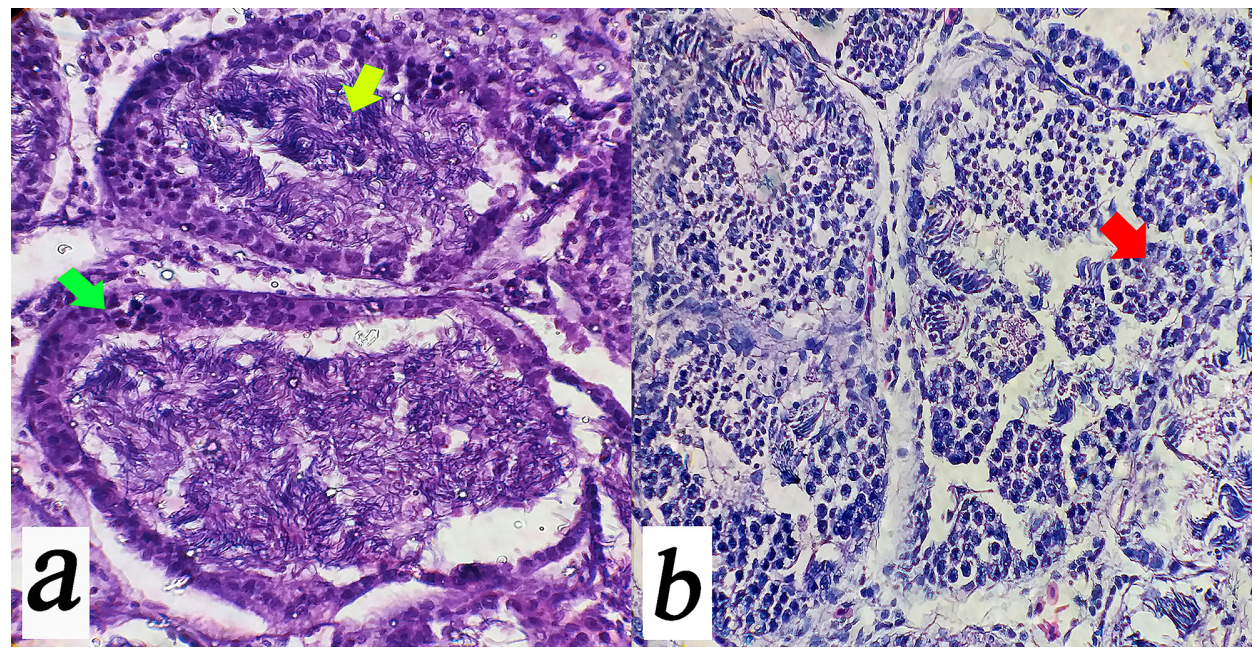

Fig. 1. Comparison of reproductive state in male $H$. savignyi during the: a) active period April, yellow arrow: spermatozoa, green arrow: spermatogonia; $b$. inactive period following the spawning season in October, red arrow: spermatocyte cyst

Our variance analysis showed that the testes differed significantly in mean weight and size across months $(\mathrm{p}<0.001)$. Scheffe's post hoc test showed that the testes differed significantly in April compared to other months. Specifically, male testes attained their greatest size and mass in April as compared to other months (Fig. 2). Consequently, these findings support the histological analysis.

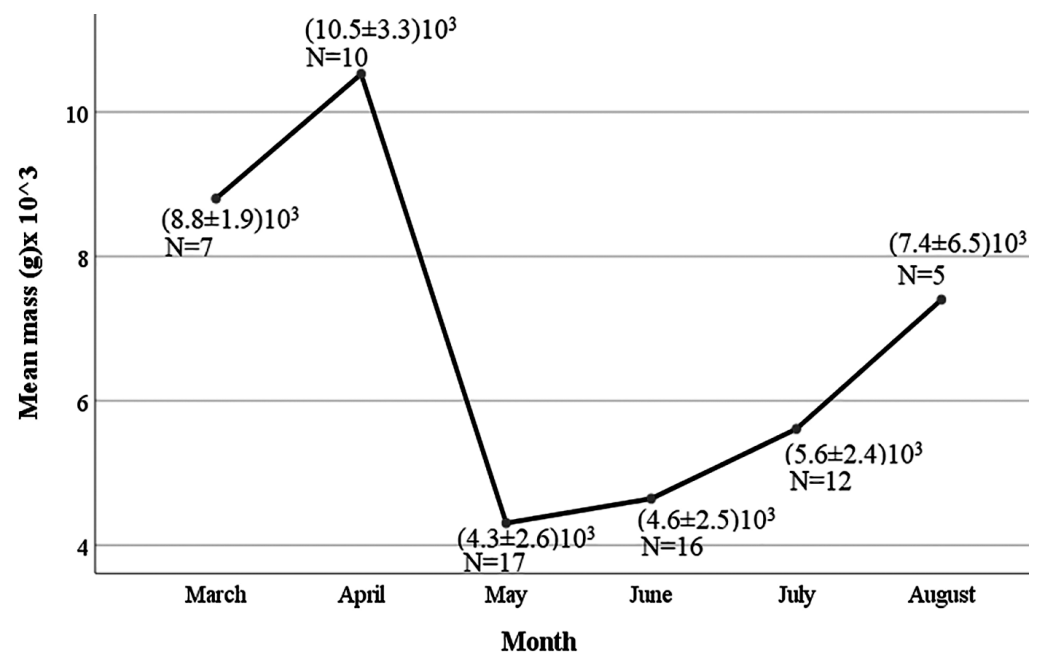

Fig. 2. Change in mean testis mass \pm standard deviation in Hyla savignyi in different months of the year 
Table 1. Comparison of life-history traits of H. savignyi in Iran. S: survival rate; ESP: life expectancy.

\begin{tabular}{lccccccc}
\hline Sex & $\mathrm{n}$ & $\begin{array}{c}\text { Average } \\
\text { age (years) }\end{array}$ & Range age & $\begin{array}{c}\text { Average } \\
\text { SVL }(\mathrm{mm})\end{array}$ & $\begin{array}{c}\text { Range SVL } \\
(\mathrm{mm})\end{array}$ & S & $\begin{array}{c}\text { ESP } \\
\text { (years) }\end{array}$ \\
\hline Female & 5 & $4.40 \pm 0.68$ & $3-6$ & $40.92 \pm 2.08$ & $36.04-47.06$ & & \\
Male & 67 & $3.63 \pm 0.13$ & $2-6$ & $38.47 \pm 0.45$ & $29.34-44.03$ & 0.73 & 4.2 \\
\hline
\end{tabular}

\section{Growth estimation}

According to our results, the first larvae completed metamorphosis (t0) about 0.3 years after egg deposition. At that time, metamorphosed larvae had total body lengths of $10 \mathrm{~mm}(\mathrm{Lt} 0)$. The growth coefficient was 0.77 in males and 0.73 in females. Both sexes had a higher maximum SVL (47.06 $\mathrm{mm}$ for females and $44.03 \mathrm{~mm}$ for males) than asymptotic SVL (SVLasym was $43.07 \mathrm{~mm}$ for females and $41.16 \mathrm{~mm}$ for males). We found that females were slightly larger than males (Table 1). Although the SDI was 0.06, indicating an intersexual difference in body length (female-biased SSD), SVL did not differ significantly among females and males according to the Mann-Whitney test; $\mathrm{P}=0.207$.
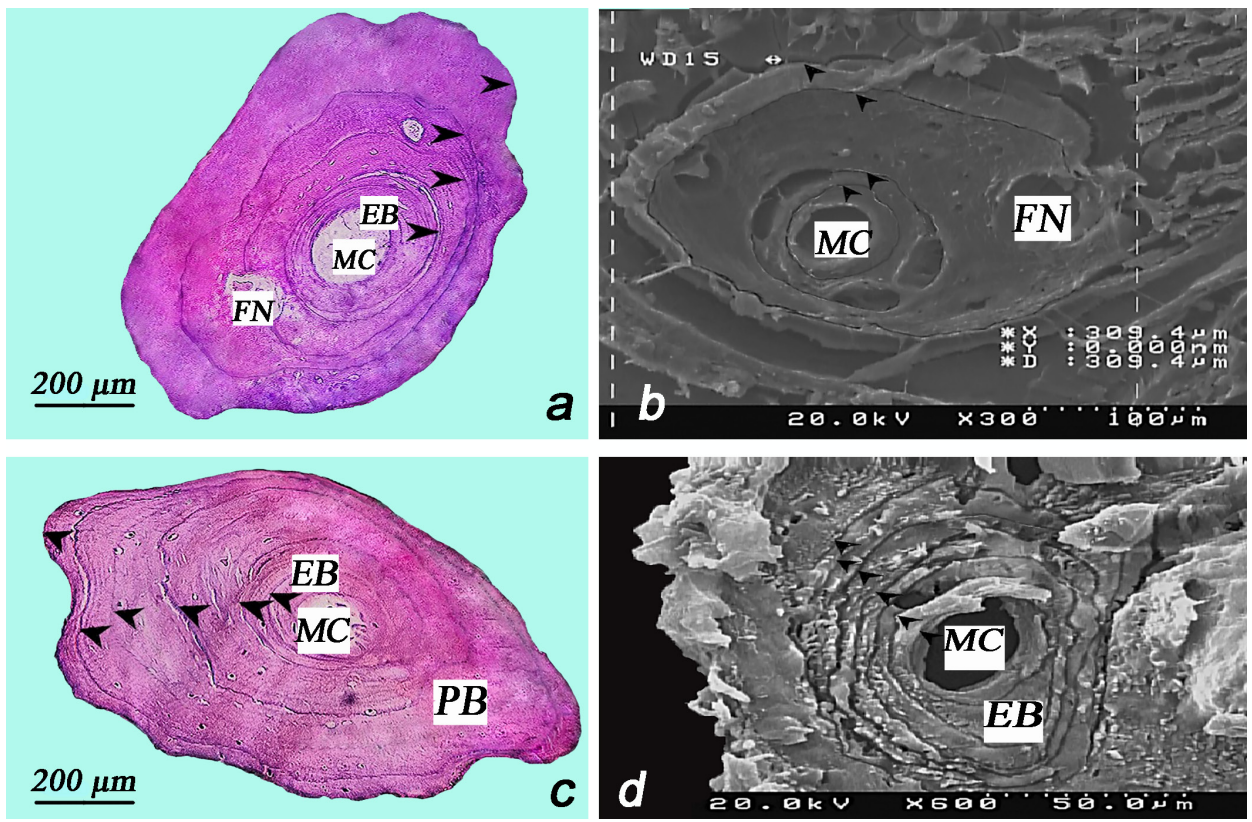

Fig. 3. Light-microscope photographs (a and c) and images from low-magnification SEM ( $b$ and $d$ ) of lines of arrested growth (LAGs) of second phalangeal bones in H. savignyi. a: 4-years old male $(S V L=42.25)$; b: 4-year old male $(S V L=40.29)$; c and d: 6-years old female $(\mathrm{SVL}=47.06)$; $\mathrm{MC}=$ marrow cavity, $\mathrm{EB}=$ endosteal bone, $\mathrm{PB}=$ periosteal bone, $\mathrm{FN}=$ nutrient foramen 


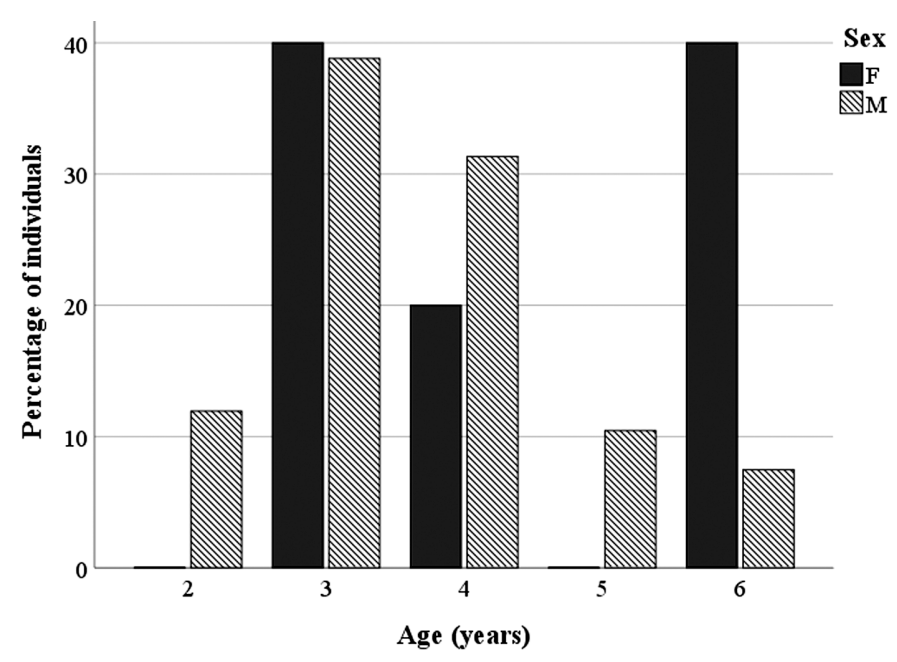

Fig. 4. Age distributions of specimens according to sex in Hyla savignyi

Bone histology and skeletochronological analysis (age structure, age at sexual maturity, longevity, and growth)

In all cross-sections, hematoxynophilic lines were marked and estimated age obtained by both direct observation in the light microscope (Fig. 3a, c) and visualization using low-magnification SEM (Fig. $3 b, d$ ). The mean age of females was $4.40 \pm 0.68$ years (range 3-6 years), while the average age in males was $3.63 \pm 0.13$ years (range $2-6$ years; Table 1 ). There was no significant difference in age structure between females and males (Mann-Whitney test; $\mathrm{W}=$ $215.5, \mathrm{P}=0.27$ ); therefore, survival rate (S) and life expectancy (ESP) calculations were combined $(S=0.73, \mathrm{ESP}=4.2$ years) for both sexes (Table 1$)$. Ages of sexual maturity were 2 or 3 years in breeding individuals, and longevity (maximum lifespan) was found to be 6 years for both sexes (Table 1 \& Fig. 4).
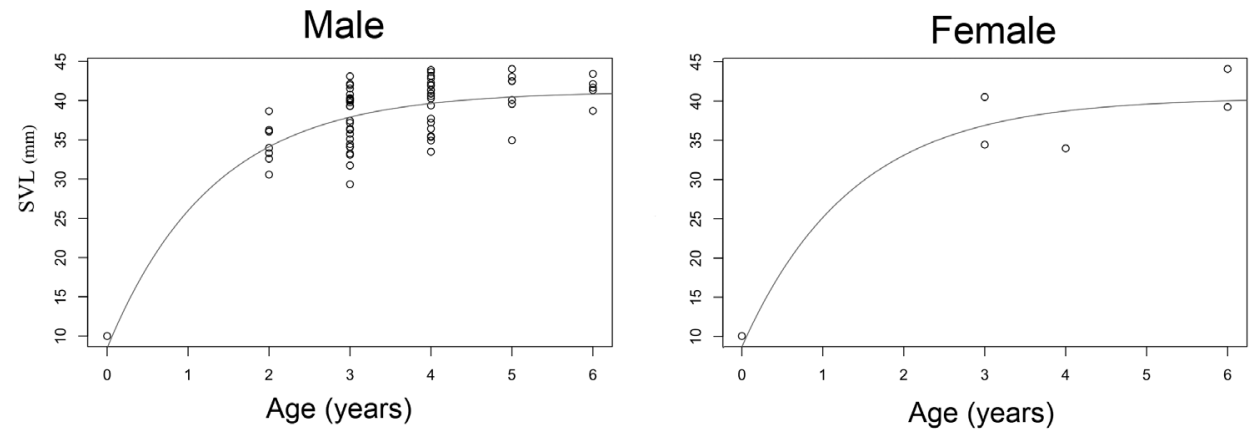

Fig. 5. Relationship between snout-vent length (SVL) and age structure of breeding female and male Hyla. savignyi 
A significant positive correlation was detected between age and body size $(\mathrm{SVL})$ in both sexes (Spearman's correlation; $\mathrm{Q}=0.51, \mathrm{P}<0.001$ ). The growth curves represented a good fit for a correlation between body size and age (Fig. 5).

\section{DISCUSSION}

Generally, three patterns have been proposed for the annual spermatogenetic cycles in anurans: discontinuous, potentially continuous, and continuous (LofTs 1974). Frogs and toads in temperate regions have evolved a discontinuous or potentially continuous spermatogenic cycle, whereas those inhabiting tropical areas often have evolved a continuous type of spermatogenic cycle (for more information, refer to Huang et al. 1996, Kaptan \& Murarhanoglu 2008). Huang et al. (1996) reported that the spermatogenetic cycle of the Taiwan endemic toad (Bufo bankorensis) is continuous. In another study, LoFTs (1974) reported that the annual distribution of germ cells in Pelophylax ridibun$d u s$ indicates that spermatogenetic activity appears to be continuous; dissimilar results were reported by Loumbourdis and Kyriakopoulou-SKLAVONOU (1991) and Kaptan and Murarhanoglu (2008) on populations from the northern part of Greece and plains of Geyve (East Marmara) respectively, where spermatogenetic activity is potentially continuous. Pesarakloo and NajibzaDEH (2019) reported that Pelophylax bedriagae spawns in early April in breeding ponds in the Khorramabad region of western Iran. The sympatric amphibian species, Bufotes variabilis (Pallas) and Hyla savignyi are not active during this season (BALOutch \& Kami 1995). Field observations of H. savignyi microscopic examination of histological sections of the testes and macroscopic analysis (testis weight and size) showed that a high level of breeding behaviour occurred in March-July, and the highest level of sperm production occurred in April. Thus, March-July was considered to be the breeding period. According to our results, accounting for the observed pattern of spermatogenetic activity and change in mass and size of the testes, the reproductive cycle of $H$. savignyi is the potentially continuous type.

According to our field observations, the metamorphosis was completed approximately 102 days after egg deposition, and body size at metamorphosis measured $10 \mathrm{~mm}$. The embryonic and larval periods in anurans vary across between species and geographically within species in the region: Toxopeus et al. (1993) describe a study of Pelodytes punctatus from France (i.e., not Iran or elsewhere in Central Asia), so it doesn't make sense to cite it here in the context of "the region" (i.e., Central Asia). For example, the metamorphosis was completed in 73 days for Rana pseudodalmatina in Golestan Province, Iran (Pesarakloo et al. 2015), and 43-90 days for P. ridibundus in Anzali Lagoon, Iran (Mirzajani et al. 2006), but 80-120 days for another population of the latter species in France (Momeni \& Zamatкesh 2005). In contrast, P. bedriagae had 
finished their development and commenced metamorphosis after 111 days (Pesarakloo \& Najibzadeh 2019).

Generally, three patterns have been proposed for sexual dimorphism in amphibians, according to body size (SSD): Female-biased (females larger than males), male- biased (males larger than females), and unbiased (males equal to females) (Zhang et al. 2016). BüLBüL et al. (2018) reported a slight female-biased SSD in the Enez population of Bombina variegata. According to our results, a female-biased SSD was observed in H. savignyi; SVLasym was $43.07 \mathrm{~mm}$ for females and $41.16 \mathrm{~mm}$ for males. Although no significant difference was observed between females and males concerning mean SVL and mean SVLasym, data obtained from the current study confirm the general patterns of body size variation in anurans and suggest that females are larger than males (Shine 1979, Serra-Cobo et al. 2000, Kupfer 2007, Reinhard et al. 2015, Zhang et al. 2016). According to previous studies, there are at least two reasons that could explain female-biased SSD in anurans. In one study, most males did not defend territories, offer resources to females, or care for offspring, and all males, small or large, were able to fertilize all eggs of any female (VARgas-Salinas 2006). Consequently, intersexual selection is not expected to favour the reproductive success of larger males (VARGAS-SALINAS 2006). Alternatively, age differences (Monnet \& Cherry 2002, Young 2005, Liao et al. 2011) and survival (VARGAs-Salinas 2006) between males and females can also explain female-biased SSD. Females are larger than males in some frogs because there are higher levels of mortality in males (MeshaKA 2001). Indeed, lower survival in males means that females have more time to grow than males (VARGAS-SALINAS 2006).

Growth coefficients were slightly higher in males (0.77) than in females (0.73). Our results are in contrast to those seen in most amphibians, which usually show higher growth coefficients in females than in males (RYSER 1988, Erişmiş \& Chinsamy 2010, Çıçek et al. 2011, Patrelle et al. 2012, Erişmiş 2018, BAşKALE et al. 2018). Large body size in females may be affected by survival (Vargas-Salinas 2006) and age differences (Monnet \& Cherry 2002, Young 2005, Liao et al. 2011). This is in agreement with our results, where the mean age of females was 4.40 years, while the average age in males was 3.63 years (Table 1). Indeed, lower survival in males means that females have more time to grow than males (VARgas-Salinas 2006). Wells (2001) argued that acoustic competition during the breeding season in frogs might explain lower local survival in males, a conclusion consistent with the literature (Tsiora \& Kyriakopoulou-Sklavounou 2002, Socha \& Ogielska 2010, ÇiçeK et al. 2011, Gül et al. 2011, Erişmiş 2018, Arisoy \& BAşKALE 2019). The life expectancy of females and males of Pelophylax caralitanus was estimated to be 6.61 and 6.15 years, respectively (ARIsoY \& BAŞKALE 2019), and the mean survival rates of females and males were calculated as 0.84 and 0.83 , respectively. Similarly, the 
survival rate in adult Rana temporaria was 0.82 in males and 0.80 in females, and the expected total longevity of frogs that reached sexual maturity was 6.1 years in males and 5.5 years in females (Miaud et al. 1999). In the present study, the survival rate (S) was calculated to be 0.73 for both sexes, with a life expectancy (ESP) of 4.2 years.

Numerous researchers (e.g. Hemelaar 1985, Ryser 1988, Kutrup et al. 2005, Altunişik 2018) have found that the age at maturity may vary between different species and populations of anurans (Miaud et al. 2000, AltunişıK 2018). In several studies, it was reported that male anurans mature earlier than corresponding females (Monnet \& Chery 2002, Matthews \& Miaud 2007, KutRup et al. 2011). Intraspecific variation in age at maturity and adult body length along geographic (altitudinal and latitudinal) gradients is welldocumented in anurans. However, patterns are often inconsistent (MIAUD et al. 1999). Arisoy and BAşKALE (2019) showed that maturity ages were 2 or 3 years in both sexes of $P$. caralitanus, whereas the age at maturity of $R$. dalmati$n a$ was determined to be 2 years (SARAsola-Pue et al. 2011). In another study, Hemelaar (1988) estimated that age at maturity was 1.77 years for males and 2.49 years for females of Bufo bufo. The maximum age for $R$. latastei recorded to date was 3 years in males and 4 years in females (Guarino et al. 2003). Our data in the present study showed that maturity ages were about 2 or 3 years in breeding individuals, and longevity (maximum lifespan) was found to be 6 years for both females and males, consistent with the results of the study of H. savignyi in Turkey (Kalayci et al. 2015). Reznick (1990) proposed a model that implies that the correlation between age and body length at maturity remains constant over different environmental conditions. Halliday and VerRELL (1988) stated that there are positive correlations between age and body size in amphibians. A strong positive correlation between SVL and age was reported for males and females of B. variegata (BüLBüL et al. 2018) and B. bombina (CogÂlniceanu \& Miaud 2003). In the present study, a significant positive correlation was detected between age and body size in both sexes of $H$. savignyi. Our results indicate that the largest individuals are almost always the oldest in both sexes and males were usually smaller and younger than females. Similar results have been reported in H. savignyi in Kermanshah province, Iran (RAstegar-Pouyani et al. 2015) and Nasiriyah province, Iraq (AljaBERI \& Al Moussawi 2020), and in H. arborea in Turkey (Ö̈zDemir et al. 2012).

$*$

Acknowledgements - We would like to thank the honourable authorities of Arak University for helping with the laboratory tasks. We also thank the anonymous reviewers for their careful reading of our manuscript and their valuable comments and suggestions.

Declaration of interest: The authors report no conflicts of interest. The authors alone are responsible for the content and writing of this article. 


\section{REFERENCES}

Adolph, S. C. \& Porter, W. P. (1996): Growth, seasonality, and lizard life histories: age and size at maturity. - Oikos 77: 267-278. https://doi.org/10.2307/3546065

Al-Jaberi, M. \& Moussawi, A. (2020): Sexual size dimorphism in Hyla savignyi Audouin, 1827 (Anura: Hylidae) from Nasiriyah Province, southern of Iraq. - Al-Qadisiyah Journal of Pure Science 25(1): 7-13. https://doi.org/10.29350/qjps.2020.25.1.1077

AltunişıK, A. (2018): The first demographic data and body size of the southern banded newt, Ommatotriton vittatus (Caudata: Salamandridae). - Acta Herpetologica 13: 13-19. https://doi.org/10.13128/Acta-Herpetol-21171

Arisoy, A. G. \& BAşKALE, E. (2019): Body size, age structure and survival rates in two populations of the Beyşehir frog Pelophylax caralitanus. - Herpetozoa 32: 195-201.

Bancroft, J. D. \& Steven, A. (1990): Theory and practice of histological technique. 3rd ed. - New York, Churdchill Livingstone.

BaşKale, E., Ulubeli, S. A. \& KaskA, Y. (2018): Age structures and growth parameters of the Levantine frog, Pelophylax bedriagae, at different localities in Denizli, Turkey. - Acta Herpetologica 13: 147-154. https://doi.org/10.13128/Acta_Herpetol-21026

BEHERA, S. (2012): Histological observation of gonads during breeding and non breeding season of Trichogaster fasciatus in Shanti Jheel, west Bengal. - Journal of Biology 1: 205-214.

Bernardo, J. (1993): Determinants of maturation in animals. - Trends in Ecology \& Evolution 8: 166-173. https://doi.org/10.1016/0169-5347(93)90142-C

Berven, K. A. (1982): The genetic basis of altitudinal variation in the wood frog Rana sylvatica. I. An experimental analysis of life-history traits. - Evolution 36: 962-983. https://doi.org/10.1111/j.1558-5646.1982.tb05466.x

Berven, K. A. \& Chadra, B. G. (1988): The relationship among egg size, density and food level on larval development in the wood frog (Rana sylvatica). - Oecologia 75: 67-72. https://doi.org/10.1007/BF00378815

Berven, K. A. \& GiLl, D. E. (1983): Interpreting geographic variation in life-history traits. Integrative and Comparative Biology 23: 85-97. https://doi.org/10.1093/icb/23.1.85

Berven, K. A., Gill, D. E. \& Smith-Gill, S. J. (1979): Counter gradient selection in the green frog, Rana clamitans. - Evolution 33: 609-623. https://doi.org/10.1111/j.1558-5646.1979. tbb04714.x

Bülbül, U., Kutrup, B., EroĞLu, A. I., Koç, H., Kurnaz, M. \& Odabaş, Y. (2018): Life-history traits of a Turkish population of the Yellowbellied Toad, Bombina variegata (Linnaeus, 1758) (Anura: Bombinatoridae). - Herpetozoa 31: 11-19.

Cardoso, A. J. \& Haddad, C. F. B. (1992): Diversidade e turno de vocalizações de anuros em comunidade neotropical. - Acta Zoologica Lilloana 41: 93-105.

Castanet, J. \& Smirina, E. M. (1990): Introduction to the skeletochronological method in amphibians and reptiles. - Annales des sciences naturelles/ Zoologie et Biologie Animale 11: 191-196.

Cheatsazan, H., Mahjoorazad, A., Rabani, V. \& Kami, H. (2005): Distribution of the Yellow-Lemon Tree Frog, Hyla savignyi Audouin, 1827 (Anura: Hylidae) in Iran. - Zoology in the Middle East 36: 109-111. https://doi.org/10.1080/09397140.2005.1063813

Çı̧̇eK, K., Kumaş, M., Ayaz, D., Mermer, A. \& Engin, Ş. D. (2011): Age structure of Levant water frog, Pelophylax bedriagae, in Lake Sülüklü (Western Anatolia, Turkey). - Basic and Applied Ecology 25: 73-80. https://doi.org/10.11160/bah.11012

CogÂlniceanu, D. \& Miaud, C. (2003): Population age structure and growth in four syntopic amphibian species inhabiting a large river floodplain. - Canadian Journal of Zoology 81: 1096-1106. https://doi.org/10.1139/z03-086 
Driscoll, D. A. (1999): Skeletochronological assessment of age structure and population stability for two threatened frog species. - Australian Journal of Ecology 24: 182-189. https://doi.org/10.1946/j.1442-9993.1999.241961.x

Duellman, W. E. \& Trueb, L. (1986): Biology of amphibians. - McGraw-Hill, New York, pp. 109-140.

Erişmiş, U. C. (2018): Age, size, and growth of the Turkish endemic frog Pelophylax caralitanus (Anura: Ranidae). - The Anatomical Record 301: 1224-1234. https://doi. org/10.1002/ar.23758

Erişmiş, U. C. \& Chinsamy, A. (2010): Ontogenetic changes in the epiphyseal cartilage of Rana (Pelophylax) caralitana (Anura: Ranidae). - The Anatomical Record 293: 18251837. https://doi.org/10.1002/ar.21241

Gibbons, M. M. \& McCarthy, T. K. (1986): The reproductive output of frogs Rana temporaria (1.) with particular reference to body size and age. - Journal of Herpetology 209: 579-593. https://doi.org/10.1111/j.1469-7998.1986.tb03613.x

Guarino, F. M., Lunardi, S., Carlomagno, M. \& Mazzotti, S. (2003): A skeletochronological study of growth, longevity, and age at sexual maturity in a population of Rana latastei (Amphibia, Anura). - Journal of Biosciences 28: 775-782.

Gül, S., Özdemir, N., ÜzüM, N., Olgun, K. \& Kutrup, B. (2011): Body size and age structure of Pelophylax ridibundus populations from two different altitudes in Turkey. - Amphibia-Reptilia 32: 287-292. https://doi.org/10.1163/017353711X559094

Halliday, T. R. \& Verrell, P. A. (1988): Body size and age in amphibians and reptiles. Journal of Herpetology 22: 253-265. https://doi.org/10.2307/1564148

Hemelaar, A. (1985): An improved method to estimate the number of year rings resorbed in phalanges of Bufo bufo (1.) and its implications to populations from different latitudes. - Amphibia-Reptilia 6: 323-341. https://doi.org/10.1163/156853885X00326

Hemelaar, A. (1988): Age, growth and other population characteristics of Bufo bufo from different latitudes and altitudes. - Journal of Herpetology 22(4): 369-388. https://doi. org/10.2307/1564332

Huang, W. S., Lin, J. Y. \& Yu, J. U. L. (1996): The male reproductive cycle of the toad, Bufo bankorensis, in Taiwan. - Zoological Studies 35: 128-137.

Jin, L., Chen, C. H., LiaO, W. (2017): Altitudinal variation in body size and age in male Spot-Legged treefrog (Polypedates megacephalus). - Russian Journal of Ecology 48: 476-481. https://doi.org/10.1134/S1067413617050083

Kami, H. G. (1995): Amphibians of Iran. - Tehran University Press, Tehran, 178 pp. [in Farsi]

Kaptan, E. \& Murarhanoglu, O. (2008): Annual morphological cycles of testis and thumb pad of the male frog (Rana ridibunda). - The Anatomical Record 291: 1106-1114. https:// doi.org/10.1002/ar.20723

Konvalina, J. D., Trauth, S. E. \& Plummer, M. V. (2018): Spermatogenesis and testicular cycle in Rough Greensnakes, Opheodrys aestivus, from Arkansas. - Journal of Herpetology 52: 185-192. https://doi.org/10.1670/16-163

Kupfer, A. (2007): Sexual size dimorphism in amphibians: an overview. Pp. 50-59. In: Daphne, J. F., Wolf, U. B. \& SzÉKely, T. (eds): Sex, size and gender roles: Evolutionary studies of sexual size dimorphism. - Oxford University Press. https://doi.org/10.1093/ac prof:oso/9780199208784.003.0006

Kutrup, B., ÇAKIR, E., ÇOLAK, Z., BüLbüL, U. \& KARAoĞLu, H. (2011): Age and growth of the green toad, Bufo viridis (Laurenti, 1768), from an island and a mainland population in Giresun, Turkey. - Journal of Animal and Veterinary Advances 10: 1469-1472. 
Kutrup, B., Yilmaz, N. \& Bulbul, U. (2005): Age structure in two populations of Triturus vittatus ophryticus at different altitudes. - Amphibia-Reptilia 26: 49-54. https://doi. org/10.1163/1568538053693314

Liao, W. B., Lu, X., Shen, Y. W. \& Hu, J. C. (2011): Age structure and body size of two populations of the rice frog Rana limnocharis from different altitudes. - Italian Journal of Zoology 78: 215-221. https://doi.org/10.1080/11250001003639590

Lofts, B. (1974): Reproduction. Pp. 107-218. In: Lofts, B. (ed.): Physiology of the amphibia. Academic Press, New York.

Loumbourdis, N. S. \& Kyriakopoulou-Sklavounou, P. (1991): Reproductive and lipid cycles in the male frog Rana ridibunda in northern Greece. - Comparative Biochemistry and Physiology. A, Comparative Physiology 99: 557-583. https://doi.org/10.1016/03009629(91)90133-w

Lovich, J. E. \& Gibbons, J. W. (1992): A review of techniques for quantifying sexual size dimorphism. - Growth Develop Aging 56: 269-269. https://doi.org/10.1006/jhev.1998.0281

Matthews, K. R. \& Miaud, C. (2007): A skeletochronological study of the age structure, growth, and longevity of the mountain yellow-legged frog, Rana muscosa, in the Sierra Nevada, California. - Copeia 2007: 986-993. https://doi.org/10.1643/00458511(2007)7[986:ASSOTA]2.0.CO;2

McCreary, B., Pearl, C. A. \& Adams, M. J. (2008): A protocol for aging anurans using skeletochronology (No. 1209). - US Geological Survey, Reston, 37 pp.

Meshaka, W. E. (2001): The Cuban Tree frog in Florida. Life history of a successful colonizing species. - University Press of Florida, 224 pp.

Miaud, C., Guyétant, R. \& Elmberg, J. (1999): Variations in life-history traits in the common frog Rana temporaria (Amphibia: Anura): a literature review and new data from the French Alps. - Journal of Zoology 249: 61-73.

Miaud, C., Guyetant, R. \& Faber, H. (2000): Age, size, and growth of the Alpine Newt, Triturus alpestris (Urodela: Salamandridae), at high altitude and a review of life history trait variation throughout its range. - Herpetologica 56: 135-144.

Mirzajani, A. R., Kiabi, B. \& Bagheri, S. (2006): Study of larval growth and population estimation of Rana ridibunda in Anzali wetland. - Iranian Journal of Biology 19: 191202. [in Persian]

Momeni, M. \& Zamatkesh, E. (2005): Study of frog farming probability of the Anzali wetland (Rana ridibunda). - The First National Congress of Aquatic and Animal Science. Tehran University, Karaj, pp. 1075-1078.

Monnet, J. M. \& Cherry, M. I. (2002): Sexual size dimorphism in anurans. - The Royal Society of London, Series B 269: 2301-2307. https://doi.org/10.1098/rspb.2002.2170

Morrison, C., Hero, J. M. \& Browning, J. (2004): Altitudinal variation in the age at maturity, longevity, and reproductive lifespan of anurans in subtropical Queensland. - Herpetologica 60: 34-44. https://doi.org/10.1655/02-68

Olgun, K., Üzüm, N., Avci, A. \& Miaud, C. (2005): Age, size and growth of the southern crested newt Triturus karelinii (Strauch 1870) in a population from Bozdağ (Western Turkey). - Amphibia-Reptilia 26: 223-230. https://doi.org/10.1163/1568538054253465

Otero, M. A., Valetti, J. A., Bionda, C. L., Salas, N. E. \& Martino, A. L. (2017): Are ploidy and age size-related? A comparative study on tetraploid Pleurodema kriegi and octoploid P. cordobae (Anura: Leptodactylidae) from Central Argentina. - Zoologischer Anzeiger 268: 136-142. https://doi.org/10.1016/j.jcz.2016.07.005 
Özdemir, M., Altunişik, A., Ergül, T., Gül, S., Tosunoglu, M., Cadeddu, G. \& Giacoma, C. (2012): Variation in body size and age structure among three Turkish populations of the treefrog Hyla arborea. - Amphibia-Reptilia 33 : 25-35.

Patrelle, C., Hjernquist, M. B., Laurila, A., Söderman, F. \& Merila, J. (2012): Sex differences in age structure, growth rate and body size of common frogs Rana temporaria in the subarctic. - Polar Biology 35: 1505-1513. https://doi.org/10.1007/s00300-012-1190-7

Pesarakloo, A. \& Najibzadeh, M. (2019): Life-history of the Levant water frog, Pelophylax bedriagae (Amphibia: Anura: Ranidae) in western Iran. - Journal of Animal Diversity 1: 11-19. https://doi.org/10.29252/JAD.2019.1.1.2

Pesarakloo, A., Rastegar-Pouyani, N., Najibzadeh, M., Rastegar-Pouyani, E., Gharzi, A. \& SHAYESTEHFAR, A. (2015): Interactive effects of temperature and food availability on the Marsh Frog (Pelophylax ridibundus) tadpoles in western Iran. - Asian Journal of Conservation Biology 4: 130-135.

Rastegar Pouyani, N., Fattahi, A., Karamiani, K. \& Takesh, M. (2015): Sexual size dimorphism in Hyla savignyi Audouin, 1827 (Anura: Hylidae) from Kermanshah Province, Western Iran. - Iranian Journal of Animal Biosystematics 11(1): 17-22.

Reinhard, S., Renner, S. \& Kupfer, A. (2015): Sexual dimorphism and age of Mediterranean salamanders. - Zoology 118: 19-26. https://doi.org/10.1016/j.zool.2014.08.002

RezNick, D. N. (1990): Plasticity in age and size at maturity in male guppies (Poecilia reticulata): an experimental evaluation of alternative models of development. - Journal of Evolutionary Biology 3: 185-203.

Rugh, R. (1951): The frog its reproduction and development. - The Blakiston Company, Toronto, $336 \mathrm{pp}$.

Ryser, J. (1988): Determination of growth and maturation in the common frog, Rana temporaria, by skeletochronology. - Journal of Zoology 216: 673-685. https://doi. org/10.1111/j.1469-7998.tb02465.x

Sarasola-Puente, V., Gosá, A., Oromí, N., Madeira, M. J. \& Lizana, M. (2011): Growth, size and age at maturity of the agile frog (Rana dalmatina) in an Iberian Peninsula population. - Zoology (Jena) 114(3): 150-154. https://doi.org/10.1016/j.zool.2010.11.009

Sasso-Cerri, E., De Faria, F. P., Freymüller, E. \& Miraglia, S. M. (2004): Testicular morphological changes during the seasonal reproductive cycle in the bullfrog Rana catesbeiana. - Journal of Experimental Zoology Part A: Comparative Experimental Biology 301: 249-260. https://doi.org/10.1002/jez.a.20023

SEber, G. A. F. (1973): The estimation of animal abundance and related parameters. - Griffin, London, $506 \mathrm{pp}$.

Serra-Cobo, J., Uiblein, F. \& Martinez-Rica, J. P. (2000): Variation in sexual dimorphism between two populations of the Pyrenean salamander Euproctus asper from ecologically different mountain sites. - Belgian Journal of Zoology 130: 39-45.

Shine, R. (1979): Sexual selection and sexual dimorphism in the Amphibia. - Copeia 1979: 297-305. https://doi.org/10.2307/1443418

Socha, M. \& Ogielska, M. (2010): Age structure, size and growth rate of water frogs from central European natural Pelophylax ridibundus-Pelophylax esculentus mixed populations estimated by skeletochronology. - Amphibia-Reptilia 31: 239-250. https://doi.org/10.1163/156853810791069119

Stearns, S. C. (1976): Life-history tactics: a review of the ideas. - The Quarterly Review of Biology 51: 3-47. 
Stearns, S. C. \& Koella, J. C. (1986): The evolution of phenotypic plasticity in life-history traits: predictions of reaction norms for age and size at maturity. - Evolution 40: 893913. https://doi.org/10.1111/j.1558-5646.1986.tb00560.x

Toxopeus, A. G., Ohм, M. \& Arntzen, J. W. (1993): Reproductive biology of the parsley frog, Pelodytes punctatus, at the northernmost part of its range. - Amphibia-Reptilia 14: 131-147. https://doi.org/10.1163/156853893X00309

Tsiora, A. \& Kyriakopoulou-Sklavounou, P. (2002): A skeletochronological study of age and growth in relation to adult size in the water frog Rana epeirotica. - Zoology 105: 55-60. https://doi.org/10.1078/0944-2006-00049

VARgas-Salinas, F. (2006): Sexual size dimorphism in the Cuban tree frog Osteopilus septentrionalis. - Amphibia-Reptilia 27: 419-426. https://doi.org/10.1163/156853806778189936

Von Bertalanffy, L. (1957): Quantitative laws in metabolism and growth. - The Quarterly Review of Biology 32: 217-231. https://doi.org/10.1086/401873

Wells, K. D. (1977): The social behaviour of anuran amphibians. - Animal Behaviour 25: 666-693. https://doi.org/10.1016/0003-3472(77)90118-X

Wells, K. D. (2001): The energetics of calling in frogs. Pp. 45-60. In: RYan, M. E. (ed.): Anuran communication. - Smithsonian Press, Washington DC.

Young, K. A. (2005): Life history variation and allometry for sexual size dimorphism in Pacific salmon and trout. - Proceedings of the Royal Society B: Biological Sciences 272: 167-172. https://doi.org/10.1098/rspd.2004.2931

Zhang, X., XIong, J. L., Lv, Y. Y., Zhang, L. \& Sun, Y. Y. (2016): Sexual size and shape dimorphism in the Wushan salamander, Liuashihi (Liu, 1950) (Urodela: Hynobiidae). - Italian Journal of Zoology 81: 368-373. https://doi.org/10.1080/11250003.2014.920927

Received August 27, 2020, accepted April 16, 2021, published August 16, 2021 
